\title{
Scholarship and Activism: A Social Movements Perspective
}

\author{
LAURENCE COX \\ National University of Ireland, Maynooth Ireland
}

\begin{abstract}
This article revisits the debate over Barker and Cox's (2011) use of Gramsci's distinction between traditional and organic intellectuals to contrast academic and activist modes of theorizing about social movements. Often misread as an attack on personal choices in career and writing, the distinction aimed to highlight the different purposes, audiences, and social relationships entailed by these different forms of theorizing. Discourses which take 'scholarship' as their starting point position 'activist' as a personal choice within an institutional field, and substitute this moral commitment for a political assessment of its effects. By contrast, few academics have undergone the political learning curve represented by social movements. This may explain the widespread persistence - beyond any intellectual or empirical credibility - of a faith in 'critical scholarship' isolated from agency, an orientation to policy makers and mainstream media as primary audiences or an unquestioned commitment to existing institutional frameworks as pathways to substantial social change. Drawing on over three decades of movement participation and two of academic work, this article explores two processes of activist training within the academy. It also explores the politics of different experiences of theoretical publishing for social movements audiences. This discussion focuses on the control of the "means of mental production" (Marx, 1965), and the politics of distribution. The conclusion explores the broader implications of these experiences for the relationship between movements and research.
\end{abstract}

KEYWORDS social movements; learning and knowledge production; Gramsci; organic intellectuals; activist scholarship

\section{Introduction: What Have the Romans Ever Done for Us?}

When Colin Barker and I posed this question 15 years ago (Barker and Cox, 2011; hereafter referred to as "Romans"), our point was not that academic social movement theory contributed nothing to understanding social 
movements; ${ }^{1}$ it was to reflect critically on what its contribution is. We adopted Gramsci's (1971) distinction between "traditional intellectuals" (those in social relationships tied to pre-existing social groups but which have since become mystified or naturalized and appear as standing above society) and "organic intellectuals" (those created by new social groups, including the representatives both of modern capital and of social movements from below). We characterized the social relationships structuring different ways of theorizing social movements as: (a) academic - ultimately shaped by the social relations of academia, such as employment, credentialization, scholarly publication, funding proposals, etc.; and (b) activist - ultimately shaped by the relationships involved in social movements. ${ }^{2}$ We went on to argue that these social positions were allied to different modes of constructing knowledge for different social purposes, which shape the form of that knowledge. Drawing on various concrete cases, in particular the experience of the Southern Non-Violent Coordinating Committee (SNCC), ${ }^{3}$ we analyzed "movement theorizing" as "an aspect of the work that people do as they try to create institutions (movements) that will enable them (indirectly, through a change in the social order) to meet needs that are not currently being met" (Barker and Cox, 2011, p. 31).

The academic and activist responses to these arguments were revealing. ${ }^{4}$ On the one hand, it has been my own most-cited piece, despite circulating almost exclusively in samizdat (via the print proceedings of a then-obscure academic/activist conference, my own far more obscure website, and in a compressed Catalan translation) for a decade before republication on a Finnish non-governmental organization (NGO) website. ${ }^{5}$ More than anything else I have written, activist researchers have mentioned it to me as expressing something they recognized from their own, often difficult, encounters within academia: social movements are knowledge producers in their own right (Eyerman and Jamison, 1991; Wainwright, 1994), but this is rarely recognized within the everyday social relations of academic knowledge production.

\footnotetext{
${ }^{1}$ In this article I use the term academia to distinguish the institutionalized social relationships of universities and other third level institutions from other forms of, for example, research, teaching, and theorizing which take place elsewhere, such as in social movement contexts (Cox, 2014a). ${ }^{2}$ There is by now quite a body of literature on the various meanings of 'activist' (e.g., Bobel, 2007; Cortese, 2015) within movements, where it can be variously a desirable or unwanted designation. As in "Romans", I am using it here to distinguish forms of intellectual practice which have an organic connection to social movements and collective action from those which do not.

${ }^{3}$ SNCC was a key organization in the US Civil Rights Movement.

${ }^{4}$ For recent critical reflections on the piece, see Cresswell \& Spandler, 2013; and McKeown, 2012 , p. 25.

${ }^{5}$ Consistent with this, many responses came in the form of conference discussions, anonymous reviewer comments, etc., rather than conscious theoretical statements. Sullivan (2004) is an early example of the latter. An extensive contemporary response, highlighting other work of mine, is Jasper (2015).
} 
On the other hand, purely academic researchers were often uncomfortable at being asked to apply the sociology of knowledge - the critical exploration of how the social relations within which 'knowledge' of any kind, whether beliefs about health, journalistic commonplaces, natural science, or religion is produced - to their own work. Like other social actors, challenging taken-forgranted attitudes to routine activities is often unwelcome (Garfinkel, 1967). The most common of these defensive responses did not advance a different sociology of knowledge, but rather (a) denied any division between academia and activism, as though planning a direct action was fundamentally the same thing as submitting a grant proposal; or (b) interpreted the distinction as being about the moral legitimacy of personal choices to operate in different modes. When 'critical', 'reflective' researchers reduce the social relationships within which they work to questions of individual moral justification, this points to the social construction of academic realities (Berger and Luckmann, 1967).

Most such responses, in the difficult circumstances of the post-Thatcher British university in particular, came from academics unused to active dialogue with other knowledge producers (such as social movements) and thus often generalized their own immersion in the narrow world of the university to a perspective on the social world. One 'critical theorist' publicly denied (at an activist/academic workshop on critical pedagogy) that anyone outside his particular tradition could achieve any distance from taking social reality for granted. Others simply treated the social relations of the university as natural and normal (although students have to be taught to master the complex rules of academic production). What was revealed was a deeply unreflexive group of social actors turning a blind eye to the complexities of an academic structure (which under other circumstances they grumbled about while struggling to negotiate successfully), and who were flummoxed by the proposition that there are differences, let alone conflicts, between universities and social movements.

More reflexive researchers, grounded in social movements, sought to 'go beyond' dichotomies or 'blur' boundaries, and here I want to suggest that there is a constitutive confusion. Individuals may of course engage in multiple sets of relationships, but it is naive to suggest that knowledge is produced outside of such relationships, or that the ways in which knowledge is produced, the audiences who enable and validate its production and distribution, and the purposes for which it is produced, do not affect both its content and its potential political uses. We may certainly ask if knowledge can be produced in ways that work within both sets of relationships, but this does not free us from such relationships. Instead, the real question becomes what the politics of doing so are, and which set of relationships tend to win out under which circumstances. Far from denying the existence of movementlinked researchers within academia (which was our situation at the time), a substantial chunk of our "Romans" piece was given over to discussing the challenges and contradictions posed by this situation. 
This article returns to these questions after more than a decade of attempting to work out the implications of "Romans" as an activist in academia. Grounded in personal experience and reflection on practice, it opens with a brief discussion of attempts at changing the shape of the academic field of social movement studies; moves to the ways in which individuals may come to inhabit both sets of social relations (academic and activist) simultaneously; and explores the distribution of knowledge as a strategically central aspect of knowledge production. The discussion concludes by noting some wider implications for the encounter between movements and higher education. ${ }^{6}$

My particular experience is located between two sets of relationships: firstly the immense collective learning embodied in, and transmitted by, the global 'movement of movements' and working-class community activism, which are both in very different ways concerned with processes of learning, reflection, and training as key political tasks; and secondly, the very diverse experiences of European academia around the multiple fields involved in researching social movements, and the particular oddities of the Irish university system. I am particularly interested in what happens when movement-based forms of knowledge and action encounter the logics of academic institutions. The article uses 'backstage' exchanges in university settings to illustrate the practical 'common sense' perspective of (mostly social science) academics and the sorts of contradictions which arise in daily practice. Theoretically, it draws on the literatures on movements, and learning and knowledge production (LKP), as they have developed within Marxism and feminism, in popular education theory, and in social movements research.

\section{A Social Movements Perspective on Academic and Activist Relationships}

It is certainly possible to enter academia from social movements, albeit far easier in some contexts than others. Most people I work with regularly are activists first, and students or academics second; we share a critical distance from university institutions and support each other in negotiating them constructively, while attempting to avoid institutional capture. 'Negotiation' is, however, a polite word for this process. As E. P. Thompson wrote, "One must make one's sensibility all knobbly - all knees and elbows of susceptibility and refusal - if one is not to be pressed through the grid into the universal mish-mash of the received assumptions of the intellectual culture" (1978, pp. 393-394). Raymond Williams, similarly, commented of the challenge of combining political commitments elsewhere with work in

\footnotetext{
${ }^{6}$ Some of the experiences discussed here are also examined in Cox (2014a) from the perspective of sociology as a discipline. Here I consider them from the perspective of social movements.
} 
academia: "I feel a coarse hard bastard beside [his character Matthew Price], but more able, I think or hope, to work and push through" (1979, p. 295).

Some people do start from a purely 'academic' identity and then move into political activism, but it is relatively rare, at least in the fields and countries I know, for various reasons. If we do not always and everywhere live in a "social movement society" (Meyer and Tarrow, 1998), it is nonetheless hard to arrive at university in the $21^{\text {st }}$ century without having been exposed to the fact that our societies are contested. Collective struggle and individual dissent is frequent; hence, one must respond either through engagement or through actively avoiding such conflict. 'Not being political', in other words, is a powerful choice, and those who have distanced themselves from their more critical and engaged peers earlier in life are less likely to change their minds later. $^{7}$

Beyond this, contemporary universities in the global North offer options for imagining that one's own activity is political by definition (Cortese, 2015). For example, academics can readily overestimate their political influence on students. Furthermore, while the partial colonization of academia by participants in post-1968 social movements brought many new approaches (Rojas, 2004), normal generational processes mean that to be radical, critical, Marxist, feminist, and so on, are themselves now often valued positions within university discourse. This has led to the strange phenomenon of academic critics of, for instance, austerity and neoliberalism who contradict their theoretical positions in their daily practice as neoliberal managers, engaged (for example) in active opposition to workplace organizing. One academic, now a professor, asked me in all seriousness, "isn't it possible to be a radical and just be interested in gradual reforms within the system?," with the implication that it was per se desirable to be 'a radical', whatever one's actions. This rhetoric replays the broader 'opinion politics' of neoliberalism, which disconnects holding opinions from practical collective action, while at the same time endowing them with enormous significance for personal identity and moral worth. Both generational and, in Ireland, geographical distance from the original contexts where the radical theories selectively drawn on in the academy were produced lead to a disembedding, ${ }^{8}$ which means that the link between ideas and practice (immediately visible, for example, in the Italian reception of Gramsci) is broken (cf. Hadot, 1995 for historical parallels).

From the other side of the division between contemplative and praxisoriented approaches, genuinely reflexive 'critical scholarship' involves recognizing that becoming aware of a systematic or structural injustice, nailing it in a hard-hitting piece of writing or publishing high-quality research on it, does not in itself change things. It must ask after the interests

\footnotetext{
${ }^{7}$ Conversely, life history exercises I have carried out regularly show that students who tell themselves that they "haven't been political" have often grown up in families with more resistance to dominant institutions than they imagine.

${ }^{8}$ See Cox, in press, on decontextualized readings of Gramsci in Ireland.
} 
underpinning particular social institutions, and the collective action (of the powerful, the wealthy, and those with high cultural status) that turn interests into institutions (Cox and Nilsen, 2014). Put another way, there are serious questions of intellectual and empirical credibility of any critique which is either disconnected from agency or unreflectingly relies on existing institutions (policy-makers, media, teaching, etc.) as a tool for the change it seeks. This realization was Marx's starting point some 170 years ago.

This is a learning curve which social movements have typically gone through collectively, and far more deeply than in most academic training. ${ }^{9}$ They have discovered that good arguments and empirical research are only as effective as the social agents who deploy them. It is not even a question of those who have an 'objective interest' in resolving the problem in question, but rather of those who are willing to act collectively around it, confront the entrenched interests that are keeping things as they are, and develop the necessary organization to win the ensuing conflicts (Touraine, 1981).

Hence my own practice is pragmatic in this sense: the practical, "thisworldly" meaning of critique (Marx, 1969a) has to support those social forces that actually embody a challenge to injustice and oppression; in other words, to help generate knowledge which would be useful to social movements from below. This, for me, is the only intellectually serious and politically credible position from which it makes sense for radicals to engage with academia.

\section{Some Core Principles: Reflecting on Practice}

I came to academia from activism in search of a day job. As an undergraduate I had combined fieldwork in Hamburg movements with the discovery of sociology and the field of social movements, which seemed to hold out the possibility of a deeper understanding of our own organizing practice in a range of movements, and I turned to that field as an activist seeking effective knowledge. However, within that field, as I encountered it once back in Ireland, there was virtually no recognition that movements create their own knowledge (Casas-Cortés, Osterweil \& Powell, 2008; Marchart, Adolphs \& Hamm, 2010; Stromquist and Hennessy, 2012).

One experienced social movements academic asked why on earth I wanted my literature review to include some of the challenging theorists of the German left, instead of confining myself to 'the literature'. Having read some extraordinarily ill-informed pieces by Anglophone academics on the German left, reliant on translations and lacking the practical or political skills to carry out the activities they were discussing, I worked my way toward a different conception of knowledge grounded on respect rather than an automatic assumption of the superiority of university knowledge. In particular, my

\footnotetext{
${ }^{9}$ On movements as learning processes, see Horton \& Freire,1990; Foley, 1999.
} 
position grew out of discussions with working-class and mature students at Waterford Institute of Technology, giving public talks to activist groups, and from conversations with two remarkable activist researchers, Martin Geoghegan and Margaret Gillan.

Geoghegan (e.g., 1999) and Gillan (e.g., 2010) were both steeped in the culture of working-class community activism (one as a youth worker, the other as a media activist) and committed to combining their own learning paths with positive benefits for their movements. In working with them, I came to understand that the conventional research trajectory, which enables bright young radicals and bright young people from disadvantaged backgrounds to insert themselves into academic careers by learning how to express their outrage at subjects they were already familiar with before starting research, but now using a suitably well-formed academic language, was sufficiently accessible and widely-distributed that supervising this kind of work was not the most useful contribution I could make.

In this context I developed a strategy of participatory action research (PAR) in social movement practice; that is, research which forms an integral part of movements' reflection and discussion on their activities in order to improve their own effectiveness. ${ }^{10}$ This put me in a contradictory situation as someone who had not formally adopted these principles for my own $\mathrm{PhD}$, although they formed the basis for a community-based oral history project which I directed in the vast working-class estate of Ballymun (north Dublin), home to a long radical history. For a number of years after my $\mathrm{PhD}$ and this project, $\mathrm{I}$ struggled to re-engage with research, not least because my thesis - which arose out of the experience of networking between Irish movements - was completed a few months before the flowering of the anti-capitalist movement of movements from 1999 onwards, and there were other and more urgent things to be done within movements (Cox, 2006). I was enough of an activist, perhaps, to do what needed to be done, but enough of an academic to worry about the apparent contradiction of telling others to do something which I did not feel an 'official' expert on.

Writing this article, it has become clearer to me that my own practice has itself been a form of PAR: as activist, movement educator, and movement publisher, I have committed myself long-term (between 5 and 16 years at time of writing) to a series of collective projects which have been PAR writ large without being consciously conceived as such. Put another way, PAR is not simply some clever academic idea, but a way of formalizing good organizing practice, translated into research terms.

Specifically, the phrase 'learning from each other's struggles', which I use to describe these projects, represents a joint learning process between social movement participants, whether expressed in political gatherings, in popular education projects, or in online fora for dialogue between movement participants and researchers (Finnegan and Cox, 2007). Each of these projects

\footnotetext{
${ }^{10}$ On the varieties of action research in social movements, see Fuster Morell, 2009.
} 
has also been a learning experience in itself, in that they have encouraged or forced us to ask "can we do this?" and "if we do this, what happens?" The answers to these questions are, perhaps, worth sharing more widely. In broad terms, they represent a practical confirmation for those of us taking part that 'learning from each other's struggles' is a viable strategy for movement development.

\section{Activist Training in the Academy? Two Pedagogical Experiences}

It is part of the "activist ABC" (Cox, 2010a, p. 303) that how we construct relationships - our approach to organizing - has crucial effects. This is true not only in social movement politics but also in different kinds of pedagogy: ${ }^{11}$ in both contexts different kinds of social relationships are consciously constructed in order to enable particular possibilities and exclude others. In other words, making clear distinctions and choices in terms of how we structure our interactions is a fundamental part of good organizing and good teaching practice, as well as being essential to clear thinking about them. Objecting on principle to "boundaries" and "dichotomies" (e.g., Sullivan, 2004 , p. 10), as though such things were bad in themselves, is to leave us unable to clarify, to ourselves or others, what it is we are doing and how it differs from anything else.

The Grassroots Gatherings are a case in point. ${ }^{12}$ In the early 2000 s, the activists who created the Gatherings to connect Irish movements agreed on two key parameters. Firstly, we did not want high-profile sessions aimed at attracting people who were not already active in movements. Using a longstanding movement distinction, the Gatherings are educational and organizing spaces geared to people who have already become social movement participants, rather than agitational events geared to mobilizing people. This then enables participants to meet as relative equals, while formal presentations are kept to a minimum. Secondly, the Gatherings are geared to practical organizing and action skills rather than to discussions about the rights and wrongs of particular issues, or theoretical positions: such discussions might attract those interested in the politics of opinion, but are already familiar to most people who actually come to weekend-long activist events.

The result was that we managed to create spaces where at least threequarters of participants were already active in social movements; hence, we

\footnotetext{
${ }^{11}$ Recent work on cultural-historical activity theory and social movements (Barker \& Krinsky, 2009; Collins, 2013; de Smet, 2015) aligns the two in ways which parallel popular education theorizing in the field.

${ }^{12}$ Between 2001 and 2015, the Gatherings have brought together activists from a wide range of different social movements in Ireland and provided an important basis for alliance-building and radical organizing (see Cox 2007; http://grassroots.pageabode.com/).
} 
could take each other's politicization processes and practical commitment as given and get down to the question of taking things further. Put another way, to make this kind of practice-oriented conversation between peers possible it is not necessary to get rid of all academics, but rather to create a space where people do not participate as academics - without seminar-length papers or impassioned arguments about the right position to hold. This then enables genuine discussion between people who have already made the jump from outrage to action and want to reflect further. ${ }^{13}$

In this context, 'learning from each other's struggles' stands opposed to the kind of patronizing approach that uses possession of Theory (Thompson, 1978) to assert ownership over other people's lived realities and practical experience. The process emphasized mutual respect, the partial nature of everyone's knowledge, but also the possibility of developing forms of understanding which are more adequate to movement purposes (Bevington and Dixon, 2005), and to do so collectively, recognizing a relationship between our different struggles. There are of course theoretical ways into this perspective via Marx's and Gramsci's theories of knowledge (Marx, 1965; Gramsci, 1991), but it would be more in keeping with those theories to represent them as derived from reflection and participation in the movement struggles of the day (Cox and Nilsen, 2014). For the Gatherings, we learned this from the wider anti-capitalist movement of movements (Pleyers, 2010). The Zapatistas, World Social Forum, and summit protests have shown the value of combining a real diversity of social movements and political languages with practical collaboration in opposition to neoliberal power (Marcos, 2002; Conway, 2011).

\section{An Activist PhD?}

I drew on these organizing experiences when developing a $\mathrm{PhD}$ program 'from and for' movements. My political commitments had convinced me that the most useful thing I could be supporting as PhD supervisor was activists carrying out PAR in their own movements, ${ }^{14}$ and I was delighted to find some extraordinary activists who agreed. Together with Martin Geoghegan and Margaret Gillan, combined with the Ballymun experience, this became a long-term engagement with some remarkable people: a cohort of activists who undertook PAR focussing on their own movement practice at a $\mathrm{PhD}$ level.

It soon became clear that any kind of fetishization - of PAR methodology as something to 'apply' or of what movements must mean in all situations had to be jettisoned if the core principle of learning from each other's

\footnotetext{
${ }^{13}$ For other experiences of activist learning spaces, see Hall, Clover, Crowther \& Scandrett, 2012; Choudry \& Kapoor, 2010.

${ }^{14}$ On participatory action research more generally, see Hall, 2005; Cahill, 2007; Pain, Kindon \& Kesby, 2007.
} 
struggles was to be maintained (cf. Autonomous Geographies Collective, 2010; Cockburn and Mulholland, 2000). The activist researchers enrolled in the $\mathrm{PhD}$ program certainly found popular agency galore, but it was not always structured in the ways presupposed by more formalized methodologies. This was true for young working-class drug users articulating their own experience and its structural causes in community education; but it was equally true for Irish environmental groups who preferred to avoid strategic kinds of education and reflection around the causes of climate change. Action research could also run into the problem of an absence of collective subjects, once a given movement had ended or where a movement was divided and facing severe repression. Here again it became necessary to ask broader questions about the meaning of action and participation in such contexts. In these situations, the researchers thought like activists in developing appropriate strategies to engage with the realities they encountered.

However, the experience of doing a $\mathrm{PhD}$ was far more costly in personal terms for many of the candidates than I had expected, despite my own struggles with academic power structures and personal sustainability. Along with 'normal' biographical experiences such as bereavement and depression, some $\mathrm{PhD}$ researchers found the tensions of movement research very hard to sustain and dropped out or changed topic completely. Others found the practical costs invested in doing a $\mathrm{PhD}$, and the pressures from the institution meant that their identities faced a constant pressure to shift from 'thinking activist' to 'radical academic'. Attempts to counter this academization process by developing a collective orientation within the group were less effective than participants' own pre-existing or newly-developed connections outside the academy, to their own movements and communities or their peers abroad, which formed the real touchstone of their practice. In the end, however, none lost their engagement and commitment to social change, or 'went native' in academia in any simple way.

\section{An Activist MA?}

A group of activist scholars at Maynooth carried some of the learning from the Grassroots Gatherings and the $\mathrm{PhD}$ program over to an initiative to develop an MA in Community Education, Equality and Social Activism (Cox, 2014b). With a background in critical community education work (Connolly, 2010), an understanding of social movement practice as inherently linked to knowledge production (Conway, 2006), and the experience of comparable courses elsewhere (Chase, 2006), the program was grounded in the proposition that if movement participants are knowing agents, by coming together they can learn particularly from those movement experiences that are most different from their own. The program is facilitated using popular education methods and with a constant dialogue with participants' own 
practice and between their different kinds of practice. We invested strongly in group development and were pleasantly surprised to find student revolts around some of the constraints of academia, as well as over our teaching methods - and for that matter over PAR as a form of research.

The one-year investment of doing an MA two days a week is, of course, far less than that involved in a $\mathrm{PhD}$, and few participants have used the course to jump into academia long-term. We had also been clear from the outset that the program was not technical training for pre-existing jobs in funded organizations. After the collapse of Irish 'social partnership', ${ }^{15}$ we set out to offer broader, strategic, and organizing skills enabling activists to create new kinds of organizations or bring their existing ones more in line with their core purpose. Consistent with this, many have used the program to change gears in their activist career, and some remarkable new projects have developed.

A fundamental aspect of the program has been its definition as a practitioner one, with subjects and dissertations defined in practice-oriented terms, and a requirement that academic knowledge account for its origins and show its 'this-worldliness' in responding to a critical and experienced audience; theses are adjudicated by an appropriate external examiner. Despite government cuts to postgraduate funding, which reduced average numbers in the program by a third, what makes the program a fruitful space is precisely its recognition of differences, and the effective creation of boundaries and use of distinctions. The space of the program is a practitioner one but is set somewhat apart from the daily grind of organizing; participants spend time specifically with their peers from other kinds of movements, and activist and academic forms of knowledge are named, recognized as such, and brought into constructive dialogue.

To return to "Romans" and to Gramsci: is it possible for some degree of 'activist theorising' - the organic intellectual activity of movements - to happen within university spaces? My answer would be a cautious yes, but not without making a systematic effort to organize effectively at each level of the process. ${ }^{16}$ Without appropriate definitions of the program, academic staff and external examiners in sympathy with its goals, students whose personal motivation derives from their movement participation, appropriate research

\footnotetext{
${ }^{15}$ From the late 1980 s, Ireland developed neo-corporatist relationships between the state, employers' bodies and trade unions. In the 1990s, these relationships were extended to include, among other things, a 'community and voluntary sector' defined so as to include many social movements (community organizing, the women's movement, GLTBQ activism, environmental groups, majority world solidarity, etc.), offering limited access to funding and policy but entailing substantial professionalization and demobilization along with a shift to service provision along lines dictated by the state (Cox, 2010b). 'Partnership' also became an important aspect of much local government activity. Since the mid-2000s, the state has increasingly turned against partnership with social movements, a shift that has accelerated with the economic crisis and austerity politics.

${ }^{16}$ See Croteau, Hoynes \& Ryan (2005) and Juris \& Khasnabish (2013) for relevant collections of experiences.
} 
methodologies, and a supportive collective process, the gravitational pull of 'traditional intellectual activity' would certainly have won out.

Activist theorizing, research, and study are distinct from their academic counterparts as social relationships and modes of action, and the sheer effort involved to carry out activist work within academic contexts underlines this point (Szolucha, 2014). The most powerful 'boundaries' and 'dichotomies' are not our creation but those which the university systematically puts in place to ensure that disciplinary logics win over others: student socialization; teaching in theory, methods, and empirical content; the means by which students are recruited and organized; staff recruitment and training; processes of examination; and curricular development. Such facts become particularly visible when trying to operate "in and against the state" (London-Edinburgh Weekend Return Group, 1980), where we have both to recognize internalized and implicit routines and to construct alternatives that can work against these and be effectively justified (for a particularly sharp distinction, see Cox, 2014b).

\section{Activist/Academic Publication: The Politics of Distribution}

I move now, more briefly, to the politics of distribution. Colleagues have sometimes asked how we recruit such remarkable students for the MA program. The answer is relatively straightforward, whether from the point of view of a 'public sociology' (Burawoy, 2005) or from an activist one: we identify who has a potential interest in working in this way, approach them as equals, and present what we are doing in their own terms. The alternative, academic, logic is in some ways far stranger: it is clear from repeated discussions with colleagues that academics often start by asking what programs make institutional sense for them to offer and then hope that people will make themselves available to solve this structural problem. With few exceptions, potential students, even postgraduates, are understood as an undifferentiated mass to be recruited through mainstream media: a commonsense picture of the world which most would reject if stated theoretically.

From an organizing point of view, the question of distribution is always a key practical one. Who do we want to speak to? Where do we find them? And how do we make our perspectives available in an appropriate language and format? While the practicalities of this have changed from the days when I used to stand over a Gestetner or collect clandestinely printed material that then needed to be mailed out or left in suitable locations for readers, the underlying logic has not: any form of political organizing that goes beyond personal contact is at the same time a politics of distribution (Downing, 2000; cf. Mattoni, 2012).

This is of course equally true of theoretical and political perspectives, and, it sometimes seems, is equally hard to grasp for radically minded academics 
lacking organizing experience. The belief that it is sufficient to argue against dominant perspectives in elite locations - or for that matter in the semiprivate academic space of a thesis or blog - is very widespread and amounts to a lingering belief in elite goodwill, or in the existence of a space of 'Truth and Justice' which can be appealed to without mediation by any mere human interests. In Ireland, perhaps, the combination of a post-colonial history of "movement-become-state" (Cox 2012), more recent forms of state cooptation of movements, and a growing tendency to require an intellectual justification for political decisions, make such beliefs particularly attractive. Why not, one might feel, just say the right thing to the people who count? In practice, whatever the merits of contestation within elite locations - which few have the status to carry off effectively - what matters politically is to speak to those who have a social and political interest in hearing radical perspectives. This also means spending less time explaining how awful things are to those who live them personally, or presenting purely technical or policy solutions that might work if only the powerful had the goodwill to undertake them, and spending more time speaking among ourselves about what we are going to do about the fact that things are bad and this is shored up by entrenched interests: in other words, discussing our own agency.

I want to briefly discuss some different strategies I have pursued with my own work, not in order to propose a single right way of doing things, but rather as a political reflection about distribution. To start with a positive case, a paper I presented at a radical summer school (Cox, 2001) was taken up by a key activist group who removed the footnotes and circulated photocopies to members, who were central to much movement organizing in that period. An experience like this obviously represents 'hitting the mark' in terms of form and content, which in turn came from extensive face-to-face and online communication with other activists.

Then and later, I have aimed to write for activists who are not afraid of theory and history, following Williams' (1989) arguments about popular knowledge. ${ }^{17} \mathrm{I}$ have paid attention to the existence of radical spaces of reflection where my own kind of work - theorizing social movements in ways that are intended to help their agency - can be used. For many years, however, I overestimated the proportion of activists who were already involved in such spaces, and assumed that my work was done once I had presented a paper to an activist gathering and had photocopies circulated. More recently, the economic crisis has forced me into much greater use of online dissemination, writing for high-distribution websites and commercial book publishing. Some of this has definitely fallen on stony ground, in the sense of being read within purely academic contexts for purely academic purposes. It has, however, been interesting to see how far this 'broadcast'

\footnotetext{
${ }^{17}$ These have important resonances in Ireland, with its long-standing traditions of working-class theory and culture outside the academy.
} 
approach has enabled connections with other activist intellectual spaces that I had no contact with or awareness of.

What becomes clear is that in many different ways successive activist generations have carved out their own spaces within academia, but in ambiguous ways. As Thompson wrote of the working class:

Having failed to overthrow capitalist society, [they] proceeded to warren it from end to end... It was part of the logic of this new direction that each advance within the framework of capitalism simultaneously involved the working class far more deeply in the status quo." (Thompson, 1965, p. 343)

Something of this is also true for activists within academia. In particular, since 1968, many different kinds of would-be radical spaces have been created in different contexts, but all have had to struggle with the wider logics of the institutions they were embedded within. The different courses of these various struggles (in different countries, disciplines, and institutions) leave participants in these spaces today with greater or lesser capacities to operate as movement participants and not as academics alone.

\section{A Journal From and For Movements}

Since about 2007, a group of well over a dozen activist researchers, organized globally and with far wider circles of collaborators, have been developing the open-access activist/academic journal Interface (Wood et al., 2013). When founded, this was the only open-access journal in social movement studies; it is no paradox in terms of the argument outlined in "Romans" that the three previously existing Anglophone journals in the field were all behind paywalls, accessible only to well-resourced First World universities. From any perspective which sees movement participants as intelligent and reflective actors, this situation was a disgrace. It is a very good thing that over the last year or two, one journal has developed an open-access blog (still however an "invited space"), a second makes occasional articles publicly available, and a series of new open-access journals have been created.

As with the projects of 'learning from each other's struggles' discussed earlier, Interface has had to make several key strategic choices, and continually finds itself struggling with the gravitational pull of the academy. It is open-access, non-profit, and depends only on our time, not on funders (it is, therefore, in conflict with the pressure for 'productivity'). Interface understands itself as a practitioner journal in the sense that each article is reviewed by a practitioner as well as by an academic researcher; of course many people can adopt both roles, but activists doing postgraduate degrees, for example, often have to be actively invited to provide activist reflections rather than reproduce the academic logics they are busy learning. 
Beyond this, though, we work hard to explore themes that we think speak to activists across movements - such as repression, movement pedagogy, media creation, social change, gender in movements - and to develop appropriate formats and an open language. With each theme we address a certain proportion of readers involved in particular movements or kinds of activity and try to include them in the wider network, so that over time we have built up quite an extensive network of theoretically minded activists and engaged researchers. Some are the same people, in different parts of their lives; a lucky few are in situations where they are able to be both at once without substantial difficulties.

Along with the politics of distribution, of course, comes a question of the ownership of the intellectual means of production, which is not easy to resolve. Important to how Interface is organized is that we are strongly diverse in our movement affiliations and political traditions, but also in our relationship to academia. Personally, I am conscious of how frequently radical journals have become projects identified with a particular generation of activists-in-academia, and attempt to suggest strategies that might avoid, or stave off, this fate. The fact that Interface is neither the property of the university, nor of a particular movement foundation or political tendency, is an important part of the contribution it can make. If it would be grandiose to attempt to speak for "the movement as a whole" (Marx, 1969b), it does attempt to make the movement as a whole visible to itself, including in the very diverse forms that movement knowledge production takes (this was the theme of our first issue: Cox and Flesher Fominaya, 2009).

In this sense, we attempt to relativize the power of academically centred spaces of theory on movements by bringing them into relationship with the other languages, formats, and spaces within which movements produce knowledge. As with book publishing, we are constructing a space within which some of the various alternative publics defined within particular countries and global regions, movements and organizations, political tendencies, and academic disciplines can encounter one another and at least start to learn from each other. In this, of course, we are drawing on movement logics, specifically the logic of the anti-capitalist movement of movements (Cox and Nilsen, 2014) initially articulated by groups like the Zapatistas, People's Global Action, and Indymedia, and expressed by de Sousa Santos (2006, p. 18) as an "ecology of knowledges."

\section{Some Broader Implications}

This article finishes in media res, with Interface and the MA still in progress and taking up most of my time. To that extent, I am still fully committed to these particular approaches and experiences as spaces where a constructive relationship between movements and researchers can unfold. Here I have attempted to reflect on what can be learned by relating these experiences to 
research on learning and knowledge production in social movements, and by noting the contrast to the social relations shaping learning and knowledge production in academia. Are there broader implications of this personal experience in terms of how movements can assert their own interests in the unequal engagement with academics? As I write this, the Greek government and its neoliberal opponents are engaging in a dramatic face-off over the possibility that another way might be possible. Without yet knowing the outcome, it is evident that the pressures of neoliberalism are determining in Williams' $(2005$, p. 32$)$ sense of "setting limits, exerting pressures". Hence whether the Greeks win or lose, they would have made no impact had they not nailed their colours to the mast and been clear about the differences between their position and loyalties, and those structuring neoliberalism. The ability to withstand contradictions is made possible in the first instance by having the courage to acknowledge them as contradictions and organize accordingly.

The same holds for movement and academic logics. Interface co-editor, Richard Pithouse (2014), has presented some very fine reflections on why poor people's movements in South Africa need to make a radical break with the left academy, as well as with the clientelist state and NGOs, in order to assert and develop their own understanding and needs rather than being used for external purposes by these more powerful agents. While our situation in Ireland is somewhat different (although with important parallels around working-class community activism), there are again two very different logics and sets of interests at play between social movements and universities, and no worthwhile result is possible without clearly recognizing this distinction (Holloway, 2010).

Put another way, if it is at all possible to operate "within and against the state', this is not by pretending that state logics (here, the structural logics of universities) do not conflict with those of popular agency and the development of movements' organic intellectual capacity (Hamm, 2013). Rather, it is by identifying clearly the differences, including the differences in power, interests, and cultural status, that we can articulate serious strategies that are not simply justifications of what we are doing anyway. The process is a difficult and painful one which, as Pithouse (2014) notes, requires constant reflexivity and discussion. The underlying pressures are such that concepts, theories, methods, and disciplines can easily be repurposed to mean the opposite of their once-radical intent, and it is only a close attention to substance that can prevent this.

The upsurge of movements around the world since 2008 has propelled many people with traditional academic training into well-meaning but fundamentally "contemplative" (Gramsci, 1999, p. 535, following Marx, 1969a) relationships with social movements. Some of these people may well be able to transform this relationship into a more active relationship of solidarity. There are also, of course, many attempts to make a quick killing in 
what is seen to be an expanding market (of publications, research grants, centres, and so on): like social democrats pretending to resist austerity and stand with movements, these have to be named for what they are.

One positive side of the upsurge is that there is now greater space for genuinely movement-related initiatives, and new generations of activists are entering academic spaces and trying to turn them to their own purposes. Our role in this should not be one of recruiting clients to our own pre-existing projects but of interest in the new experiments and projects, and of solidarity in opening our own academic spaces to them and participating in their spaces. Concretely, the criterion for 'activist scholarship', following Gramsci's reflections on the Southern Question (1966), should be the extent to which we manage to reshape the concrete institutional structures of academic life undergraduate teaching, postgraduate training, research, publication, distribution, and so on - in ways which enable: (a) the further development of robust organic theory rather than teaching ex-activists to say approved things in suitably polished ways; (b) a critical dialogue of solidarity between movement processes of learning and knowledge production and their academic counterparts; and (c) a deepening connection to popular movements visible in processes such as recruitment, texts, action research, personal trajectories, dissemination and - hopefully - victories.

Our ability to reshape academic structures in these ways will never be general - or accidental - in universities within capitalist societies. It requires collective effort and intention, allied to movements and willing to confront both academic power relations and our own "mind-forg'd manacles," as Blake put it. In other words, we must learn not only through a critical reflection on our social situation and relationships, but also by praxis geared to changing that situation and creating more radical relationships.

\section{References}

Autonomous Geographies Collective. (2010). Beyond scholar activism: Making strategic interventions inside and outside the neoliberal university. ACME: An International EJournal for Critical Geographies, 9(2), 245-275.

Barker, C., \& Krinsky, J. (2009). Movement strategizing as developmental learning. In H. Johnston (Ed.), Culture, protest, and social movements (pp. 209-225). Farnham: Ashgate.

Barker, C., \& Cox, L. (2002/2011). 'What have the Romans ever done for us?' Activist and academic forms of theorizing. Helsinki: Into. Retrieved from http://www.intoebooks.com/essay/what-have-the-romans-ever-done-for-us/

Berger, P., \& Luckmann, T. (1967). The social construction of reality. Harmondsworth: Penguin

Bevington, D., \& Dixon, C. (2005). Movement-relevant theory. Social Movement Studies, 4(3), 185-208.

Bobel, C. (2007). I'm not an activist, though I've done a lot of it. Social Movement Studies, 6(2), $147-159$.

Burawoy, M. (2005). For public sociology. American Sociological Review, 70(February), 4-28.

Cahill, C. (2007). Repositioning ethical commitments: Participatory action research as a relational praxis of social change. ACME: An International E-Journal for Critical Geographies, 6(3), 360-373. 
Casas-Cortés, M., Osterweil, M. \& Powell, D. (2008). Blurring boundaries: Recognizing knowledge-practices in the study of social movements. Anthropological Quarterly, 81(1), 17-58.

Chase, S. (2006). Activist training in the academy: Developing a Master's program in environmental advocacy and organizing at Antioch New England Graduate School (Unpublished doctoral dissertation). Antioch University, Yellow Springs, OH.

Choudry, A., \& Kapoor, D. (2010). Learning from the ground up. London: Palgrave.

Cockburn, C., \& Mulholland, M. (2000). Analytical action, committed research. In A. Byrne \& R. Lentin (Eds.), (Re)searching women (pp. 119-139). Dublin: Institute for Public Administration.

Collins, C. (2013). Language, Marxism and the grasping of policy agendas. In C. Barker, L. Cox, J. Krinsky \& A. G. Nilsen (Eds.), Marxism and social movements (337-356). Leiden: Brill.

Connolly, B. (2010). Community based adult education. In P. Peterson, E. Baker \& B. McGaw (Eds.), International Encyclopedia of Education (3 ${ }^{\text {rd }}$ ed.). (pp. 120-126). Oxford: Elsevier.

Conway, J. (2006). Praxis and politics. New York: Routledge.

Conway, J. (2011). Activist knowledges on the anti-globalization terrain. Interface: A Journal For and About Social Movements, 3(2), 33-64.

Cortese, D. (2015). I'm a 'good' activist, you're a 'bad' activist, and everything I do is activism. Interface: A Journal For and About Social Movements, 7(1), 215-246.

Cox, L. (2001). Globalisation from below? Paper presented at the William Thompson Weekend School, Cork, Ireland.

Cox, L. (2006). News from nowhere. In N. Hourigan \& L. Connolly (Eds.), Social movements and Ireland (210-229). Manchester: Manchester University Press.

Cox, L. (2007). The Grassroots Gatherings. Red and Black Revolution, 12, 17-21.

Cox, L. (2010a). The interests of the movement as a whole. Interface: A Journal For and About Social Movements, 2(1), 298-308.

Cox, L. (2010b). Another world is under construction? Social movement responses to inequity and crisis. Irish Left Review. Retrieved from http://www.irishleftreview.org/search/another+world+is+under+construction

Cox, L. (2012). Gramsci in Mayo: A Marxist perspective on social movements in Ireland. Helsinki: Into. Retrieved from http://www.into-ebooks.com/essay/gramsci-in-mayo/

Cox, L. (2014a). Movements making knowledge: A new wave of inspiration for sociology. Sociology, 48(5), 954-971.

Cox, L. (2014b). A Masters for activists. Interface: A Journal For and About Social Movements, 6(1), 335-341.

Cox, L. (in press). The southern question and the Irish question. In M. B. Jørgensen \& Ó. G. Agustín (Eds.), Immigration and new civil society alliances. London: Pluto.

Cox, L., \& Flesher Fominaya, C. (2009). Movement knowledge. Interface: A Journal For and About Social Movements, 1(1), 1-20.

Cox, L., \& Nilsen, A. (2014). We make our own history. London: Pluto.

Cresswell, M., \& Spandler, H. (2013). The engaged academic. Social Movement Studies 12(2), $138-154$.

Croteau, D., Hoynes, W., \& Ryan, C. (2005). Rhyming hope and history. Minneapolis: University of Minnesota Press.

de Smet, B. (2015). A dialectical pedagogy of revolt. Leiden: Brill.

Downing, J. (2000). Radical media. New York: Sage.

Eyerman, R., \& Jamison, A. (1991). Social movements. Cambridge: Polity.

Finnegan, F., \& Cox, L. (2007). The Grassroots Gatherings as popular education. Plenary address presented at the $4^{\text {th }}$ International Popular Education Network Conference, Maynooth, Ireland.

Foley, G. (1999). Learning in social action. London: Zed.

Fuster Morell, M. (2009). Action research. Interface: A Journal For and About Social Movements, 1(1), 21-45.

Garfinkel, H. (1967). Studies in ethnomethodology. New Jersey: Prentice-Hall.

Geoghegan, M. (1999). The politics of exclusion: Community development as a social 
movement. In C. Barker \& M. Tyldesley (Eds.), Proceedings of the Fifth International Conference on Alternative Futures and Popular Protest. Manchester: Manchester Metropolitan University.

Gillan, M. (2010). Class, voice and state (Unpublished doctoral dissertation). National University of Ireland, Maynooth.

Gramsci, A. (1966). La questione meridionale. Roma: Riuniti.

Gramsci, A. (1971). Selections from prison notebooks. London: Lawrence \& Wishart.

Gramsci, A. (1991). Il materialismo storico e la filosofia di Benedetto Croce. Roma: Riuniti.

Gramsci, A. (1999). Further selections from prison notebooks. London: ElecBook.

Hadot, P. (1995). Philosophy as a way of life. Oxford: Blackwell.

Hall, B. (2005). In from the cold? Convergence, 38, 5-24.

Hall, B., Clover, D., Crowther, J., \& Scandrett, E. (Eds.). (2012). Learning and education for a better world: The role of social movements. Rotterdam: Sense.

Hamm, M. (2013). Engagierte Wissenschaft zwischen partizipativer Forschung und reflexiver Ethnographie. In B. Binder, F. von Bose, K. Ebell, S. Hess \& A. Keinz (Eds.), Eingreifen, Kritisieren, Verändern!? Münster: Westfälisches Dampfboot.

Holloway, J. (2010). Crack capitalism. London: Pluto.

Horton, M., \& Freire, P. (1990). We make the road by walking. Philadelphia: Temple University Press.

Jasper, J. (2015). Activism and scholarship. Paper presented at the Politics and Protest Workshop, City University of New York, New York.

Juris, J., \& Khasnabish, A. (2013). Insurgent encounters. Durham, NC: Duke University Press.

London-Edinburgh Weekend Return Group (1980). In and against the state $\left(2^{\text {nd }}\right.$ ed.). London: Pluto Press.

Marchart, O., Adolphs, S. \& Hamm, M. (2010). Bewegungspraxis und 'organische Theorie' Zur Rezeption und Produktion theorieförmiger Diskurse durch soziale Bewegungen am Beispiel der Prekarisierungsbewegung. Österreichischer Zeitschrift für Politikwissenschaft, 1: $73-88$.

Marcos, S. (2002). Our word is our weapon: Selected writings. J. P. de Leon (Ed.). New York: Seven Stories Press.

Marx, K. (1845/1969a). Thesen über Feuerbach. In, Marx-Engels Werke, Band 3 (pp. 5ff.). Berlin Dietz Verlag: Berlin. Retrieved from http://www.mlwerke.de/me/me03/me03_005.htm

Marx, K. (1848/1969b). The manifesto of the Communist Party. In, Marx/Engels selected works, volume 1. (S. Moore \& F. Engels, Trans.) (pp. 98-137). Moscow: Progress Publishers. Retrieved from https://www.marxists.org/archive/marx/works/1848/communistmanifesto/ch02.htm

Marx, K., \& Engels, F. (1845-6/1965). The German ideology, part I. Retrieved from https://www.marxists.org/archive/marx/works/1845/german-ideology/ch01b.htm

Mattoni, A. (2012). Media practices and protest politics: How precarious workers mobilise. Farnham: Ashgate.

McKeown, M. (2012). Linking the academy and activism (Unpublished doctoral dissertation). University of Central Lancashire, Preston.

Meyer, D., \& Tarrow, S. (Eds.). (1998). The social movement society. Lanham, MD: Rowman and Littlefield.

Pain, R., Kindon, S., \& Kesby, M. (2007). Participatory action research. In S. Kindon R. Pain, \& M. Kesby (Eds.), Participatory action research approaches and methods (pp. 26-32). London: Routledge.

Pithouse, R. (2014, September 17). Notes on praxis for the RGS Panel on the co-production of urban contestation (Web log comment). Retrieved from http://readingfanon.blogspot.ie/2014/09/notes-on-praxis-for-rgs-panel-on-co.html

Pleyers, G. (2010). Alter-globalization: Becoming actors in a global age. Cambridge: Polity.

Rojas, C. (2004). 1968 as a turning-point in historical thinking. História, 23(1-2), 197-208.

Sousa Santos, B. (2006). The rise of the global left. London: Zed.

Sullivan, S. (2004). We are heartbroken and furious! Engaging with violence in the (anti)globalisation movement(s) (Working Paper, Centre for the Study of Globalisation and Regionalisation). Coventry, UK. Retrieved from http://eprints.bbk.ac.uk/6070/ 
Szolucha, A. (2014). No stable ground: Real democracy in the Occupy movement (Unpublished doctoral dissertation). National University of Ireland, Maynooth.

Thompson, E. P. (1965). The peculiarities of the English. Socialist Register, 1965, 311-362.

Thompson, E. P. (1978). The poverty of theory. London: Merlin.

Touraine, A. (1981). The voice and the eye. New York: Cambridge University Press.

Wainwright, H. (1994). Arguments for a new left. Oxford: Blackwell.

Williams, R. (1979). Politics and letters. London: Verso.

Williams, R. (1958/1989). Culture is ordinary. Resources of hope (pp. 3-14). London: Verso.

Williams, R. (1980/2005). Base and superstructure in Marxist cultural theory. Culture and materialism (pp. 31-49). London: Verso.

Wood, L., Waterman, P., Motta, S., Mattoni, A., Majavu, M., Humphrys, E., . . Cox, L. (2013). Interface tenth issue. Interface: A Journal For and About Social Movements, 5(2), 1-14. 